Journal of Economic, Business and Accounting (COSTING)

Volume 2 Nomor 1, Juli-Desember 2018

e-ISSN : 2597-5234

https://doi.org/10.31539/costing.v2i1.368

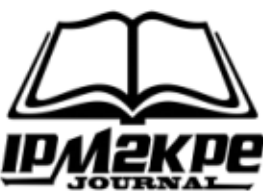

\title{
KEBIJAKAN PENGENTASAN KEMISKINAN MELALUI DANA DESA DAN PENGUAT OTONOMI DESA
}

\section{POVERTY REDUCTION POLICY THROUGH VILLAGE FUNDS AND VILLAGE AUTONOMY STRENGTHENERS}

\author{
Citra Etika \\ STIE Prabumulih \\ etikacitra@ymail.com
}

\begin{abstract}
The Village Fund is one of the policies made by the government to alleviate poverty in the village and strengthen village autonomy. The use of Village Funds is used in the field of village development and the field of community empowerment, of the total Village Funds channeled to the Village 75 percent for the development sector while for the community empowerment sector only 25 percent so that the way to overcome poverty is still relatively small. The objectives to be achieved in this study are to find out about poverty reduction policies through the Village Fund and strengthening village autonomy in Prabumulih City. The research was conducted in the villages of Jungai, Sinar Rambang, Rambang Senuling, Karangan, Talang Batu, Kemang Tanduk. The method in this study is a qualitative method using Focus Group Disussion (FGD), interviews with parties related to poverty alleviation issues (officials of the Village Consultative Body, Village Chief, Village Treasurer, Village Secretary, Planning Head, Head of Public division, head of finance division, Head of Government, Head of People's Welfare, Head of construction division, community leaders). The results of this study are that the Prabumulih City Government has implemented policies by gradually channeling Village Funds based on village performance. However, villages in Prabumulih City have not fully focused on poverty alleviation efforts. This can be seen from the APB Village Responsibility Report at the expenditure point in the field of community empowerment which is used for "posyandu" empowerment activities, Up2K, SisKeuDes training activities. Furthermore, the number of poor people in Prabumulih City is still high, namely BPS data of 43,464 people.
\end{abstract}

Keywords: Poverty Alleviation Policies, Village Funds, Village Autonomy

\section{ABSTRAK}

Dana Desa merupakan salah satu kebijakan yang dibuat pemerintah untuk pengentasan kemiskinan di desa dan memperkuat otonomi desa. Penggunaan Dana Desa digunakan untuk bidang pembangunan desa dan bidang pemberdayaan masyarakat, dari total Dana Desa yang di salurkan ke Desa 75 persen untuk bidang pembangunan sedangkan untuk bidang pemberdayaan masyarakat hanya 25 persen sehingga cara untuk mengatasi kemiskinan masih relatif kecil. Tujuan yang ingin dicapai dalam penelitian ini yakni untuk mengetahui kebijakan pengentasan kemiskinan melalui Dana Desa dan penguatan otonomi Desa di Kota Prabumulih. Adapun penelitian ini dilakukan di desa Jungai, Sinar Rambang, Rambang Senuling, Karangan, Talang Batu, Kemang Tanduk. Metode dalam penelitian ini adalah metode kualitatif yakni menggunakan Focus Group Disussion (FGD), wawancara dengan pihak-pihak yang berhubungan dengan masalah pengentasan kemiskinan (pejabat Badan Permusyawaratan Desa, Kepala Desa, Bendahara Desa, Sekretaris Desa, Kaur Perencanaan, Kaur Umum, Kaur Kauangan, Kaur Pemerintah, Kaur Kesejahteraan Rakyat, Kaur Pembangunan, tokoh 
masyarakat). Hasil penelitian ini adalah Pemerintah Kota Prabumulih telah melakukan kebijakan dengan cara penyaluran Dana Desa secara bertahap berdasarkan pada kinerja desa. Namun desa-desa di Kota Prabumulih belum sepenuhnya fokus pada upaya pengentasan kemiskinan. Hal ini dapat terlihat dari Laporan Pertanggungjawaban APBDesa pada poin belanja bidang pemberdayaan masyarakat yang digunakan untuk kegiatan pemberdayaan posyandu, Up2K, Kegiatan pelatihan SisKeuDes. Selanjutnya jumlah penduduk miskin yang ada di Kota Prabumulih masih tinggi yakni data BPS sejumlah 43.464 jiwa.

Kata Kunci : Kebijakan Pengentasan Kemiskinan, Dana Desa, Otonomi Desa

\section{PENDAHULUAN}

Otonomi daerah merupakan perwujudan dari pelaksanaan kebijakan pemerintah yang didasarkan pada pertimbangan bahwa daerah lebih mengetahui kebutuhan dan standar pelayanan bagi masyarakat didaerahnya, sehingga pemberian otonomi daerah diharapkan dapat memacu kesejahteraan masyarakat didaerah (Johanna, 2011). Pelaksanaan otonomi daerah tidak seutuhnya sesuai dengan harapan untuk kesejahteraan masyarakat, hal ini dapat dilihat dari masih tingginya tingkat kemiskinan di Indonesia.

Kemiskinan merupakan masalah kompleks dan tidak lagi dipahami hanya sebatas ketidakmampuan ekonomi tetapi juga kegagalan memenuhi hak dasar dan perbedaan perlakuan bagi seseorang atau sekelompok orang dalam menjalani kehidupan secara bermatabat. Hak-hak dasar yang diakui secara umum meliputi terpenuhinya kebutuhan pangan, kesehatan, pendidikan, pekerjaan, perumahan, air bersih, pertanahan, sumber daya alam dan lingkungan hidup, rasa aman dari perlakuan atau ancaman tindak kekerasan dan hak untuk berpartisipasi dalam kehidupan sosial politik, baik bagi perempuan maupun laki-laki (Aneta, 2010). Pemerintah daerah melakukan pengetasan kemiskinan mulai dari elemen terkecil di daerah yakni pembangunan desa.

Menurut Undang-undang No. 6 Tahun 2014 tentang desa adalah kesatuan masyarakat hukum yang memiliki batas wilayah yang berwenang untuk mengatur dan mengurus urusan pemerintah, kepentingan masyarakat setempat berdasarkan prakarsa masyarakat, hak asal usul, dan/atau hak tradisional yang diakui dan dihormati dalam sistem pemerintah Negara Republik Indonesia. Pemerintah memberikan kesempatan kepada desa untuk mengurus rumah tangganya sendiri dengan diberikannya kebijakan tentang dana desa. Menurut peraturan pemerintah Nomor 22 Tahun 2012 tentang dana desa yang bersumber dari pendapatan dan belanja negara. Dana desa adalah dana yang bersumber dari anggaran pendapatan dan belanja negara (APBN) yang diperuntukan bagi desa, yang transfer melalui anggara pendapatan belanja daerah (APBD) kota.

Otonomi Kota Prabumulih dimulai pada tahun 2001, ditandai dengan diberlakukannya UndangUndang Nomor 6 Tahun 2001 tentang pembentukan Kota Prabumulih. Kota Prabumulih merupakan pemekaran dari kabupaten Muara Enim. Jumlah penduduk Kota Prabumulih tahun 2015 adalah sebanyak 177.078 jiwa dengan penduduk miskin sebanyak 43.464 jiwa (Badan Pusat Statistik, 2017). Hal ini mendorong pemerintah daerah mengeluarkan kebijakan mengenai penguatan otonomi desa, ditandai dengan Undang-Undang Nomor 06 Tahun 2014 tentang Desa. 
Kota Prabumulih terdiri dari enam kecamatan, yaitu kecamatan Prabumulih Timur, Prabumulih Barat, Prabumulih Selatan, Prabumulih Utara, Cambai dan Rambang Kapak Tengah. Jumlah penduduk Kota Prabumulih tahun 2015 adalah sebanyak 177.078 jiwa dengan penduduk miskin sebanyak 43.464 jiwa (Badan Pusat Statistik, 2017). Hal ini menunjukan bahwa Kota Prabumulih masih memiliki masalah kemiskinan. Sejak tahun 2015 Pemerintah Kota Prabumulih telah mendapatkan dana desa yang salurkan ke desa-desa yang ada di Kota Prabumulih. Pemerintah Kota Prabumulih mendapatkan dana desa pada tahun 2017 adalah sebesar Rp 12.836.000.000,- dibagikan ke desadesa di Kota Prabumulih dipergunakan untuk mengurangi tingkat kemiskinan melalui penggunaan dibidang pembangunan desa dan bidang pemberdayaan masyarakat.

Berdasarkan permasalahan diatas maka penelitian ini bertujuan untuk mengetahui kebijakan pengentasan kemiskinan melalui dana desa dan penguatan otonomi desa di Kota Prabumulih.

\section{METODE PENELITIAN}

\section{Waktu dan tempat pelaksanaan}

Waktu pelaksanaan dimulai dari tanggal 25 Januari 2018 sampai dengan 25 Juli 2018. Tempat pelaksanaan di desa-desa Kota Prabumulih yakni desa Jungai, Sinar Rambang, Rambang Senuling, Karangan, Talang Batu, Kemang Tanduk.

\section{Teknik Pengumpulan Data}

Penelitian ini menggunakan

Focus Group Disussion (FGD) dan Wawancara. Focus Group Disussion $(F G D)$ digunakan disetiap desa (Desa Jungai, Sinar Rambang, Rambang Senuling, Karangan, Talang Batu, Kemang Tanduk), dengan menyiapkan moderator yang berperan sebagai Fasilitator dalam diskusi dan diikuti oleh 4 orang responden ahli yakni kepala desa, Sekretaris desa, Bendahara desa, Badan Permusyawaratan Desa (BPD).

Wawancara yang digunakan peneliti adalah wawancara yang terstruktur secara tatap muka kepada sejumlah responden disetiap desa dengan memfokuskan pada kebijakan pengentasan kemiskinan melalui dana desa. Adapun pihak-pihak yang berhubungan dengan masalah pengentasan kemiskinan (pejabat BPD, Kepala Desa, Bendahara Desa, Sekretaris Desa, Kaur Perencanaan, Kaur Umum, Kaur Kauangan, Kaur Pemerintah, Kaur Kesejahteraan Rakyat, Kaur Pembangunan, tokoh masyarakat).

\section{Metode Analisis}

Metode analisis dalam penelitian ini menggunakan metode analisi deskriptif kualitatif, yakni mendeskriptifkan kebijakan pengetasan kemiskinan melalui dana desa.

\section{HASIL DAN PEMBAHASAN}

Keinginan pemerintah Kota Prabumulih yang terbesar adalah menuju kesejahteraan masyarakat didaerah Kota Prabumulih. Hal ini sesuai dengan visi Kota Prabumulih yang tertuang dalam RPJMD (Rencana Pembangunan Jangka Menengah Daerah) Kota Prabumulih, yakni "Terwujudnya Kota Prabumulih sebagai kota Prima dan berkualitas" selanjutnya misi Kota Prabumulih "Mewujudkan peningkatan kualitas dan profesionalisme aparatur dalam tata pemerintah yang baik inovatif dan enterpreneurship".

Perwujudan visi dan misi tersebut tidaklah mudah harus disertai dengan kebijakan dan usaha yang tepat. Dilihat dari jumlah penduduk Kota 
Prabumulih dan jumlah penduduk miskin Kota Prabumulih dapat digambarkan dengan grafik dibawah ini

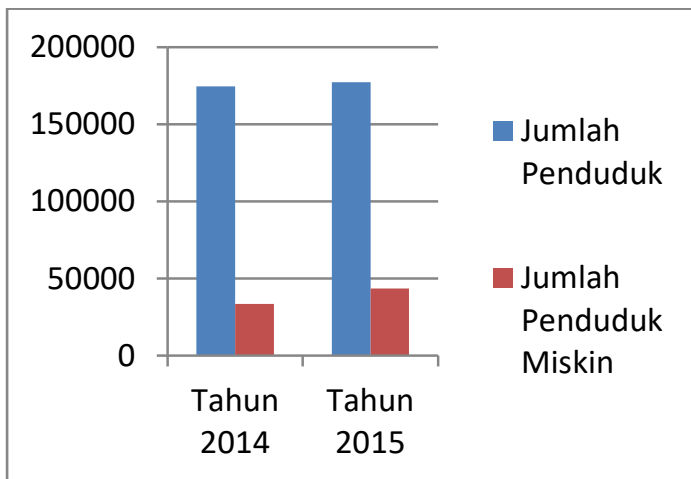

Sumber: Badan Pusat Statistik Kota Prabumulih, 2013

\section{Gambar 1. Perkembangan Jumlah Penduduk dan Penduduk Miskin Kota Prabumulih}

Berdasarkan gambar 1 dapat diketahui bahwa jumlah penduduk miskin di Kota Prabumulih meningkat dari tahun 2014-2015, yakni dari 37.935 jiwa menjadi 43.464 jiwa. Padahal pemerintah Kota Prabumulih telah melakukan upaya pengentasan kemiskinan. Melalui kebijakankebijakan berikut, yakni: Program Indonesia Pintar (PIP), Program Kartu Indonesia Sehat (KIS), Program Raskin, Program beda rumah yang dilakukan bagi masyarakat Kota Prabumulih yang dananya berasal dari zakat mal pegawai negeri sipil Kota Prabumulih dibawah naungan Baznas Kota Prabumulih.

Selain kebijakan diatas pemerintah Kota Prabumulih menggeluarkan kebijakan untuk mewujudkan kesejahteraan masyarakat Kota Prabumulih melalui dana desa yang digunakan oleh desa-desa di Kota Prabumulih. Kebijakan pemerintah tersebut tertuang dalan Peraturan Walikota Prabumulih Nomor 7 Tahun 2017 tentang Tata Cara Pembagian dan Penetapan Rincian Dana Desa. Sebelumnya kebijakan ini merupakan kebijakan Presiden Joko Widodo melalui program dana desa. Berikut rincian dana desa yang dibagikan didesa-desa Kota Prabumulih, yakni:

Tabel 1. Rincian Dana Desa Tahun 2017 Kota Prabumulih

\begin{tabular}{|c|c|c|c|}
\hline No & Kecamatan & Desa & $\begin{array}{c}\text { Pagu Dana Desa } \\
\text { Per-Desa (Rp) }\end{array}$ \\
\hline 1. & $\begin{array}{l}\text { Rambang } \\
\text { Kapak } \\
\text { Tengah }\end{array}$ & $\begin{array}{l}\text { Rambang } \\
\text { Senuling }\end{array}$ & Rp. $\quad 959.623 .000,-$ \\
\hline 2. & $\begin{array}{l}\text { Rambang } \\
\text { Kapak } \\
\text { Tengah }\end{array}$ & Jungai & Rp. 1.174.511.000,- \\
\hline 3. & $\begin{array}{l}\text { Rambang } \\
\text { Kapak } \\
\text { Tengah }\end{array}$ & $\begin{array}{l}\text { Talang } \\
\text { Batu }\end{array}$ & Rp. 1.044.966.000,- \\
\hline 4. & $\begin{array}{l}\text { Rambang } \\
\text { Kapak } \\
\text { Tengah }\end{array}$ & Karangan & Rp. $1.092 .405 .000,-$ \\
\hline 5. & $\begin{array}{l}\text { Rambang } \\
\text { Kapak } \\
\text { Tengah }\end{array}$ & $\begin{array}{l}\text { Sinar } \\
\text { Rambang }\end{array}$ & Rp. $\quad 952.651 .000,-$ \\
\hline 6. & $\begin{array}{l}\text { Rambang } \\
\text { Kapak } \\
\text { Tengah }\end{array}$ & $\begin{array}{l}\text { Kemang } \\
\text { Tanduk }\end{array}$ & Rp. 1.114.523.000,- \\
\hline
\end{tabular}

Sumber : Lampiran Perwako No. 7 Tahun 2017

Berdasarkan tabel 1. Dana Desa yang diterima desa terbesar yakni di desa Jungai yakni sebesar Rp 1.174.511.000. Pemerintah desa jungai menggunakan dana desa di bidang pembangunan desa, bidang pemberdayaaan masyarakat. Adapun rincian penggunaan dana desa di desa Jungai yakni untuk kegiatan pengembangan budidaya cabe, kegiatan pemberdayaan posyandu, Up2K, Kegiatan pelatihan SisKeuDes, usaha pangkas rambut, usaha kelompok menjahit, bimtek perencanaan desa.

Tahun 2015 pemerintah melalukan kebijakan mengenai dana desa, hal ini juga yang diterapkan di Kota Prabumulih. Dana desa Kota Prabumulih sebesar Rp 12.839.000.000,- yang dibagikan ke desa-desa di Kota Prabumulih, berdasarkan hasil Focus Group Disussion (FGD) dan wawancara di desa Jungai, Sinar Rambang, Rambang Senuling, Karangan, Talang Batu dan Kemang Tanduk, maka dapat diketahui 
bahwa penggunaan dana desa untuk bidang pembangunan desa sebesar $\mathrm{Rp}$ 9.629.250.000,- atau sebesar 75 persen, bidang pemberdayaan masyarakat sebesar Rp 3.209.759.000,- atau sebesar 25 persen.

Desa Jungai, Sinar Rambang, Rambang Senuling, Karangan, Talang Batu dan Kemang Tanduk belum mengoptimalkan sumber daya yang tersedia di desa tersebut. Hal ini dilihat dari belum optimalnya Badan Usaha Milik Desa (BUMDES) dan belum dibentuknya Koperasi milik desa. Kedua badan usaha ini dapat di jadikan wadah memberdayakan masyarakat dalam pengelolaannya sehingga dapat membantu pendapatan individual masyarakat.

\begin{tabular}{ccc}
\multicolumn{2}{c}{ BUMDES diharapkan juga } \\
mampu menstimulasi dan
\end{tabular}
menggerakkan roda perekonomian di pedesaan. Aset ekonomi yang ada di desa harus dikelola sepenuhnya oleh masyarakat desa. Substansi dan filosofi BUMDes harus dijiwai dengan semangat kebersamaan dan self help sebagai upaya memperkuat aspek ekonomi kelembagaannya. Pada tahap ini, BUMDes akan bergerak seirama dengan upaya meningkatkan sumbersumber pendapatan asli desa, menggerakkan kegiatan ekonomi masyarakat di mana peran BUMDes sebagai institusi payung dalam menaungi. Upaya ini juga penting dalam kerangka mengurangi peran freerider yang seringkali meningkatkan biaya transaksi dalam kegiatan ekonomi masyarakat melalui praktek rente (Nurcholis 2011;Ni Wayan, 2007).

$$
\text { Badan Usaha Milik Desa }
$$
(BUMDES) di desa Jungai, Sinar Rambang, Rambang Senuling, Karangan, Talang Batu dan Kemang Tanduk digunakan untuk tempat menyimpan barang sewaan yakni menyewakan peralatan catering dan tenda, tempat usaha pulsa elektrik. Sedangkan diwilayah desa tersebut banyak sumber daya alamnya yang dapat dieksplor seperti memberdayakan nanas Kota Prabumulih, kerajinan tangan dan jenis usaha lainnya. Sehingga Badan Usaha Milik Desa (BUMDES) dapat berfungsi secara optimal.

Selanjutnya Koperasi dari desa Jungai, Sinar Rambang, Rambang Senuling, Karangan, Talang Batu dan Kemang Tanduk belum ada yang membuat koperasi milik desa. Alasannya adalah penduduk setempat lebih memilih bertani karet dibandingkan dengan menjadi pengurus Koperasi. Padahal, dengan adanya koperasi, maka rakyat kecil terbebas dari lintah darat yang memberi pinjaman dengan bunga tinggi. Selain itu, rakyat pedesaan terbebas dari tengkulak yang membeli hasil panen dengan harga rendah. Pada akhirnya, mereka bisa mengelola keuangan atau hasil panen secara gotong royong dan berdasar asas kekeluargaan (Alfred, 1989).

\section{PENUTUP \\ Kesimpulan}

Pemerintah Kota Prabumulih telah melakukan beberapa upaya peretasan kemiskinan, seperti kebijakan Program Indonesia Pintar (PIP), Program Kartu Indonesia Sehat (KIS), Program Raskin, Program beda rumah bagi masyarakat Kota Prabumulih, namun upaya-upaya tersebut belum mampu mengurangi tingkat kemiskinan yang ada. Pada tahun 2015 kebijakan Pemerintah Kota Prabumulih yakni menyalurkan dana desa guna memaksimalkan upaya pengentasan kemiskinan

Penyaluran Dana Desa dilakukan secara bertahap berdasarkan kinerja desa-desa masing-masing. 
Namun desa-desa di Kota Prabumulih belum mengoptimalkan penggunaan dana desa dalam upaya pengentasan kemiskinan. Hal ini dapat terlihat dari Laporan Pertanggungjawaban APBDesa pada poin belanja bidang pemberdayaan masyarakat yang digunakan untuk kegiatan pemberdayaan posyandu, Up2K, Kegiatan pelatihan SisKeuDes, usaha pangkas rambut, usaha kelompok menjahit, bimtek perencanaan desa .Selanjutnya jumlah penduduk miskin yang ada di Kota Prabumulih masih tinggi yakni data BPS sejumlah 43.464 jiwa.

Saran

Sebaiknya tiap-tiap desa di Kota Prabumulih dapat mengoptimalkan dana desa dengan memberdayakan Badan Usaha Milik Desa (BUMDES) dan mendirikan kopersi dalam upaya pengentasan kemiskinan.

\section{DAFTAR PUSTAKA}

Aneta, Asna, (2010). Implementasi Kebijakan Program Penanggulanga Kemisikinan Perkotaan (P2KP) di Kota Gorontalo, Jurnal Administrasi Publik, 1(1),55-65.

Badan Pusat Statistik. (2017). Kota Prabumulih dalam angka. Kota Prabumulih.

Budiani, Ni Wayan, (2007). Efektivitas Program Penanggulangan Pengangguran Karang Taruna "Eka Taruna Bhakti" Desa Sumerta Kelod Kecamatan Denpasar Timur Kota Denpasar, Jurnal Ekonomi dan Sosial, 2(1),49-57.

Hanel Alfred. (1989). Organisasi Koperasi: Pokok-pokok Pikiran Mengenai Organisasi Koperasi dan Kebijaksanaan Pengembangannya di NegaraNegera Berkembang, UNPAD, Bandung
Peraturan Pemerintah. (2012). Peraturan Pemerintah Nomor 22 Tahun 2012 tentang dana desa yang bersumber dari pendapatan dan belanja negara.

Peraturan Walikota Prabumulih, (2017). Peraturan Walikota Prabumulih Nomor 7 Tahun 2017 tentang Tata Cara Pembagian dan Penetapan Rincian Dana Desa.

Johanna, Maria. (2011). Analisis Pengaruh Pengeluaran Pemerintah di Sektor Pensdidikan dan Kesehatan Terhadap Pengetasan Kemiskinan Melalui Peningkatan Pembangunan Manusia di Provinsi Jawa Tengah. Jurnal Dinamika Ekonomi Pembangunan, 1(1).

Undang-Undang. (2011). Undang Undang Nomor 6 Tahun 2001 tentang pembentukan Kota Prabumulih.

Undang-Undang. (2014). Undang Undang Nomor 06 Tahun 2014 tentang Desa. 